\title{
The impact of shadow banking on the implementation of Chinese monetary policy
}

\author{
Tommaso Gabrieli ${ }^{1} \cdot$ Keith Pilbeam $^{2} \cdot$ Bingxi Shi $^{3}$
}

Published online: 6 December 2017

(C) The Author(s) 2017. This article is an open access publication

\begin{abstract}
This paper empirically analyses the relationship between the shadow banking system and implementation of monetary policy in China using the VECM methodology. We show that an increase in the size of shadow banking sector increases the independence of bank lending from the policies of the People Bank of China. We also find that Shadow Banking works in an asymmetric fashion in that it amplifies increases in the money supply but weakens the effects of restrictive interest rate-based monetary policy decisions.
\end{abstract}

Keywords Shadow banking $\cdot$ Chinese economy $\cdot$ Monetary policy

JEL classification $\mathrm{E} 44 \cdot \mathrm{E} 50 \cdot \mathrm{G} 21 \cdot \mathrm{G} 23$

\section{Introduction}

Given the increasing global importance of the Chinese economy, there is a growing debate in both academic and policy circles on the functioning of Chinese monetary policy and its effects on the real economy. This literature presents mixed results, due to major identification issues. ${ }^{1}$ Chinese monetary policy seems unconventional given

${ }^{1}$ See for example Sun (2013) for a review.

Keith Pilbeam

k.s.pilbeam@city.ac.uk

Tommaso Gabrieli

t.gabrieli@ucl.ac.uk

Bingxi Shi

bingxi1919@sina.com

1 Bartlett School of Planning, University College London, London, UK

2 Department of Economics, City, University of London, London, UK

3 Fubon Bank China, Suzhou, China 
Western standards and it is not clear what are all the factors affecting the money supply. In particular, while Chinese monetary policy is extensively conducted by restrictions and loan quotas on the official banking sector, there is also a sizable non-regulated shadow banking sector that could in principle reinforce or weaken the monetary policy decisions. In turn, monetary policy decisions could in principle take into account the dynamics of the non-regulated sector and respond to it.

The economics literature has pointed to various channels through which monetary policy can impact the real economy, but in the Chinese context there are various open questions. While increases in bank reserve requirements appears to reduce economic activity and inflation, it is not clear whether changes in Chinese interest rates also have a substantial impact on economic activity and inflation. Moreover, it is not clear whether other measures of changes in credit conditions, such as shocks to M2 or lending levels/ quotas, have an impact once bank reserves and interest rates are taken into account.

Two recent research papers on the topic reach different conclusions and exemplify the ongoing debate. Fernald et al. (2014) claim that the monetary policy transmission channels in China have moved closer to those of Western market economies and become more effective. Conversely, Hou and Wang (2013) test the effect of reserve requirements on the lending channel and find that as the degree of market-based banking increases, China's monetary policy transmission through the bank lending channel weakens. In both articles bank lending is increasingly independent from the People's Bank of China (PBOC), but it is still an open question whether this support, weakens or amplifies the effects of monetary policy.

To address these questions it is important to notice that the bank lending channel in China is not standard because of the growing size of the largely unregulated shadow banking sector. Our paper focuses on the Shadow Banking sector in China partly because of the potentially negative effects that it could have on the national and even global financial stability and to add to the growing research on the topic in recent years. Most of the recent research on Chinese shadow banking has focused on its institutional features and implications for financial stability, without making an explicit connection between the Chinese shadow banking and monetary policy. Our paper aims to fill this gap by presenting an empirical analysis of the role of the shadow banking system in the implementation of Chinese monetary policy.

The paper is structured as follows. Section 2 reviews the recent research on the Chinese shadow banking system from an institutional perspective and aims to describe its essential features, Section 3 outlines the Chinese shadow banking system. Section 4 presents our empirical analysis and Section 5 concludes.

\section{The Chinese shadow banking sector an institutional review}

The shadow banking sector has become a well-known worldwide phenomena since the sub-prime loans crisis which exploded in 2007. The first use of the term is attributed to Paul McCulley - a senior executive at PIMCO - who during a speech in September $2007^{2}$ defined a shadow bank as "a levered-up financial intermediary whose liabilities

\footnotetext{
${ }^{2}$ Speech at the annual financial symposium hosted by the Kansas City Federal Reserve Bank in Jackson Hole, Wyoming. 
are broadly perceived as of similar money-goodness and liquidity as conventional bank deposits." Shadow banking is nowadays a broadly used concept but not uniquely defined. For example - in another famous speech in the aftermath of the financial crisis - the former president of the Federal Reserve Ben Bernanke gave the following definition" : "Shadow banking consists of a variety of institutions and markets that, collectively, implement traditional banking functions-but do so outside, or in ways only loosely linked to, the traditional system of regulated depository institutions." Since then, the Financial Stability Board has published more than 40 reports on the topic and formally defined Shadow Banking as ${ }^{4}$ : "A system of credit intermediation that involves entities and activities outside the regular banking system, focusing on credit intermediation that takes place in an environment where prudential regulatory standards and supervisory oversight are either not applied or are applied to a materially lesser or different degree than is the case for regular banks engaged in similar activities."

From these definitions it appears clear that shadow banks are financial firms that perform similar functions and assume similar risks to banks, but by being outside the formal banking sector they generally lack the standard safety nets, such as guaranteed deposit insurance or access to lender of last resort facilities and typically operate under a much lower level of regulatory oversight. Those features generally imply a difficult trade-off for policymakers between the positive effects that shadow banks can have on economic growth, by making financial services cheaper and more widely available, and the risks that this implies for financial stability due to lower safety margins and less regulation.

Influential early policy papers on the USA shadow banking system by Pozsar and Singh (2011) and Pozsar et al. (2012) stress the function of shadow banking in satisfying the demand of the mainstream investment management sector for maturity transformation, through a wide range of securitization and secured funding techniques such as asset-backed commercial paper, asset-backed securities (ABS), collateralized debt obligations and repurchase agreements (repos). In general, the principal function of any bank is maturity transformation, given that lenders prefer deposits to be of a shorter maturity than borrowers, who typically require loans for longer periods. Banks are able to achieve this transformation by qualitative asset transformation, in other words by exploiting the fact that only a small fraction of depositors have liquidity needs at a given time. As such, a bank can store a small fraction of its deposits in the form of liquid assets (readily convertible to cash) and lend out the rest in the form of term (illiquid) loans. In the US experience credit intermediation through shadow banking, unlike traditional banking which involves a simple process of deposit-taking and originating loans that are held to maturity, employs a more complicated process which relies in large part on securitization to achieve maturity transformation. At the deposit end of this type of shadow banking are wholesale investors (providers of funds) typically using the repo market and money market mutual funds to provide shortterm loans while at the loan origination end are traditional banks and other financial institutions. The two ends are then connected by a complex intermediation chain of shadow banks transforming the original loans into securitized products and then using those securities as collateral to obtain short-term funding. It is now widely accepted that

\footnotetext{
${ }^{3}$ See Bernanke (2012).

${ }^{4}$ See FSB (2013).
} 
in the US, since the late 90's, the shadow banking system provided sources of funding for credit by converting opaque, risky, long-term assets into money-like short-term liabilities. Many recent research papers ${ }^{5}$ have studied how maturity and credit transformation in the shadow banking system contributed first to credit-fueled asset bubbles and then to the credit crunch and the 2007-09 financial crisis.

Shadow banking has been rapidly growing in many Western economies as well as in China for the past two decades. Many experts on the banking industry of China generally agree that shadow banking in China presents significant differences compared to the one in Western developed countries and that it represents a challenge for the future financial stability of the Chinese economy. Despite the growing interest in Chinese shadow banking sector, there are only a small number of research articles on the topic, with some of those only published in Chinese language. ${ }^{6}$

Chinese research shows that complex financial instruments like Asset Backed Securities (ABS) do not dominate the Chinese Shadow Banking system, see for example, Li et al. (2014). Unlike shadow banking in the US which is largely dependent on capital markets and wholesale funding, Chinese shadow banking is mainly driven by commercial banks. In a typical Chinese shadow banking operation, a commercial bank savings and lending business is moved off-balance sheet by creating a shadow trust company which typically operates under lesser regulation standards. More specifically, Li and Tian (2012) describe that shadow banking in China consists of three parts of the financial services:

1) Bank internal off-balance sheet services, e.g. wealth management products and securitization,

2) Credit creation services, e.g. non-banking financial intermediaries like entrust loans (loans made on behalf of non bank financial corporations) and non-banking trust loans.

3) Informal finance services, e.g. illegal private banks and less regulated small banks including Guarantee Corporation, Small-loan Company and Private Equity Fund.

Other Chinese publications - see for example PBOC (2012) - provide a similar account and classify the shadow banking system into three equivalent categories: bankdominated shadow banks, non-banking financial intermediaries and unregulated or less regulated shadow banks. A recent report by Elliott et al. (2015) provides a very informative account of the main features of Chinese shadow banking system by reviewing some of the Chinese research and official PBOC reports. It appears that shadow banking in China is largely driven by regulatory arbitrage and attempts by regulated banks to avoid regulatory constraints. They outline how shadow banking in China can be understood in the context of a system which remains dominated large state-controlled banks and in which the state provides a great deal of direction to banks, through a variety of regulations as well as formal and informal guidance. It is understood that those constraints have become sufficiently binding so that business has quickly and increasingly moved to shadow banks in the last few years.

\footnotetext{
${ }^{5}$ See for example Brunnermeier (2009), Gennaioli et. al (2013), Adrian and Ashcraft (2012).

${ }^{6}$ See FRBSF (2013), Li (2014) among the few examples of international research papers. Xianrong (2009), PBOC (2012), Wang and Li (2013) are instead commonly cited Chinese publications.
} 
Such banking regulation can in turn to be viewed in the context of the government monetary policy and the role of state-owned banks. An interesting account of the development of the PBOC policies is provided by Sun (2013). The PBOC was established on December 1st 1948, it was the only bank in China before the economic reforms, combining the functions of a central bank and commercial banks. With the 1984 central bank reform, the regular commercial banking activities were separated from the PBOC and passed to four newly established state-owned commercial banks, while the PBOC became exclusively a central bank. The objectives of its monetary policy were defined in the People's Bank of China Act (promulgated in 1995) as "to maintain the stability of the value of the currency and thereby promote economic growth".

The PBOC therefore appears to pursue monetary policy with multiple objectives of price stability, economic growth and exchange rate stability. Until 1997 the PBOC implemented monetary policy through the so-called credit plan. This plan implied that the PBOC set the quantitative bank-specific loan quotas -which were precise lending ceilings for individual financial institutions- and provided liquidity to those banks which then allocated credit to government-preferred subsectors and projects. ${ }^{7}$ According to the credit plan, banks adjusted their lending activities to meet the loan quotas, but this direct control over the quantity of lending of individual banks led to a mismatch between credit supply and demand hindering the efficient allocation of credit. In 1996 the PBOC introduced the growth rates of monetary aggregates (M1 and M2) as nominal anchors and adopted them, together with the credit quotas, as its intermediate targets. Since January 1998, bank-specific credit quotas have been formally abolished and the PBOC has set the target for the total bank lending and used it as one of its intermediate targets as well. Elliott et al. (2015) provide a summary of the other main regulatory constraints that are pushing business away from regulated banks towards shadow banks:

- The limit of bank loans to deposits of $75 \%$

- Regulators discourage lending to certain industries, e.g. in recent years to the fast appreciating residential real estate sector.

- Most non-bank channels have lower capital and liquidity requirements than regulated banks.

- Shadow banks are not subject to bank limits on loan or deposit rates.

- Shadow banking avoids costly PBOC reserve requirements.

Interestingly, this regulatory arbitrage is explicitly recognized by the PBOC in its definition of shadow banking: they define "China's shadow banking [system] as credit intermediation involving entities and activities outside the regular banking system" that serves to provide "liquidity and credit transformation" and "which could potentially" be a source of "systemic risk or regulatory arbitrage". 8

\footnotetext{
${ }_{7}$ On this see also Montes-Negret (1995).

${ }^{8}$ See PBOC (2013).
} 


\section{Chinese shadow banking instruments and operations}

As extensively discussed by Gao and Wang (2014) all definitions of shadow banking pose practical difficulties, since just like other definitions of banking the definition will vary from jurisdiction to jurisdiction due to their different cultures and traditions. Another difficulty lies in the practical application of the definitions. In China, for example, it is difficult to draw the line between those institutions and activities that are guaranteed by the government and those that are not. Formally, there is no guarantee system for bank deposits, but up until recent times virtually everyone assumed that the government would in practice protect bank deposits. ${ }^{9}$ Furthermore, shadow banking is a catch-all term rather than a category: it encompasses a very broad range of heterogeneous activities ranging from well-established, simple and normally low-risk practices (such as money market mutual funds) to new, exotic and poorly understood transactions and this can make broad generalizations misleading.

It is fair to say that there is no consensus on which activities should be included and this creates challenges for the measurement of the shadow banking sector. Elliott et al. (2015) report a range of estimates of the size of the shadow banking sector in China calculated by financial institutions. ${ }^{10}$ They report that depending on the definition and estimates of some important statistics, six reasonable estimates in the recent past produced figures ranging from about RMB 5 trillion to RMB 46 trillion, or roughly 8 to $80 \%$ of the size of China's GDP. Similarly, comparing the features of shadow banking in China and in Western countries, Wang and Li (2013) suggest that Chinese shadow banking activities could be potentially defined according to different criteria:

1) Regulation - this can be understood as the definition of the Financial Stability Board.

2) Organization - it recognizes the shadow banking system as the non-banking financial institutions that operate in complicated financial derivative markets (e.g. Collateralized Debt Obligations and Credit Default Swaps).

3) Function - it defines the shadow banking system as the credit intermediation that is endowed with the functions of the credit swap, maturity transformation and liquidity transformation.

As already mentioned, financial derivative products and maturity transformation do not appear to describe the majority of the shadow banking activity in China, therefore the first regulation criteria has been the one adopted is analyzing shadow banking in China. The shadow banking system in China may be identified with the securitization services of commercial banks without legal or with insufficient regulations, such as the collaboration between banks and trust companies. ${ }^{11}$ The estimate of its size should include asset management financial products of commercial banks, entrust funds, nondiscount bank acceptance bills, private lending and credit services and private equity funds. It appears to be especially dominated by financial products like asset

\footnotetext{
${ }^{9}$ This was evident during recent defaults of some SB institutions, see for example Economist (2014a) and Economist (2014b).

${ }^{10}$ See also Zhu, Ng, and Jiang (2013) and FSB (2014).

${ }^{11}$ See for example Xiao et al. (2012).
} 
management financial pools, insurance products, trust funds, investment funds and entrusted loans.

As described by FRBSF (2013), a typical Chinese shadow banking transaction can be one in which a state-owned company borrows from a state-owned bank at a government-set low interest rate; the company then re-lends the money at a significantly higher interest rate to a private trust company that is part of the shadow banking sector which is free of loans' regulatory constraints; that Trust company then lends the money to a more speculative sector of the economy, such as real estate development, which would not have been possible for the state-owned bank. Trust companies are financial firms in China that have a quite flexible charter, combine elements of banks and asset managers and have wide latitude to operate across the financial sector. These companies expanded rapidly because their wealth management products (WMPs) offer rates of return as much as $15 \%$.

WMPs form another very important component of the Chinese shadow banking system. These are investment products that provide a return based on the performance of a pool of underlying assets. Typically the underlying investment is a single large loan or a pool of loans. WMPs are generally offered to customers as higher-yielding alternatives to traditional deposits by banks or Trust companies. WMPs are included in discussions of shadow banking in large part because they are a close substitute for bank deposits. In principle, banks simply manage WMP assets on behalf of clients, with the client, not the bank, exposed to losses if the assets decline in value. Anecdotal evidence and polling results demonstrate that in practice WMP investors strongly assume that the target return of these products is effectively guaranteed by any bank or Trust associated with the product. Sponsors have apparently rescued a number of failed WMPs, although this has been done with little transparency. ${ }^{12}$

The relationship between Trust companies and WMPs has been highlighted as one of the possible drivers for future financial instability in the Chinese economy. Banks do not hold the described loans on their balance sheets or set aside capital against their potential defaults. Instead, they typically extend them via intermediary Trust Companies that are not allowed to accept deposits or formally loan out money, but are allowed to manage it. Trust companies create investment products like WMPs which banks market in return for a commission. The Trust can then invest the money gathered through a WMP in a given company. The typical lending cycle of a WMP is presented in Fig. 1. Moreover, there is a further layer of lack of transparency as WMPs are usually of short maturity and therefore banks have the flexibility to move assets and liabilities on- and off-balance-sheet by choosing the start-and end-dates of WMPs so as to maintain a low average deposit balance to avoid high reserve requirements. The true nature of the connection between WMPs, trust companies and traditional banks is illustrated in Fig. 2. Numerous market reports have pointed out to the high risks of these products and the issues related to the lack of transparency. ${ }^{13}$

Further complexity arises from the fact that Trust companies and banks are interconnected through ownership and business operations. It is common practice for banks to own controlling shares in Trust companies. Furthermore, in the so-

\footnotetext{
${ }^{12}$ See the already mentioned Economist (2014a) and Economist (2014b).

${ }^{13}$ See for example Tao and Deng (2013) and Zhu, Ng, and Jiang (2013).
} 


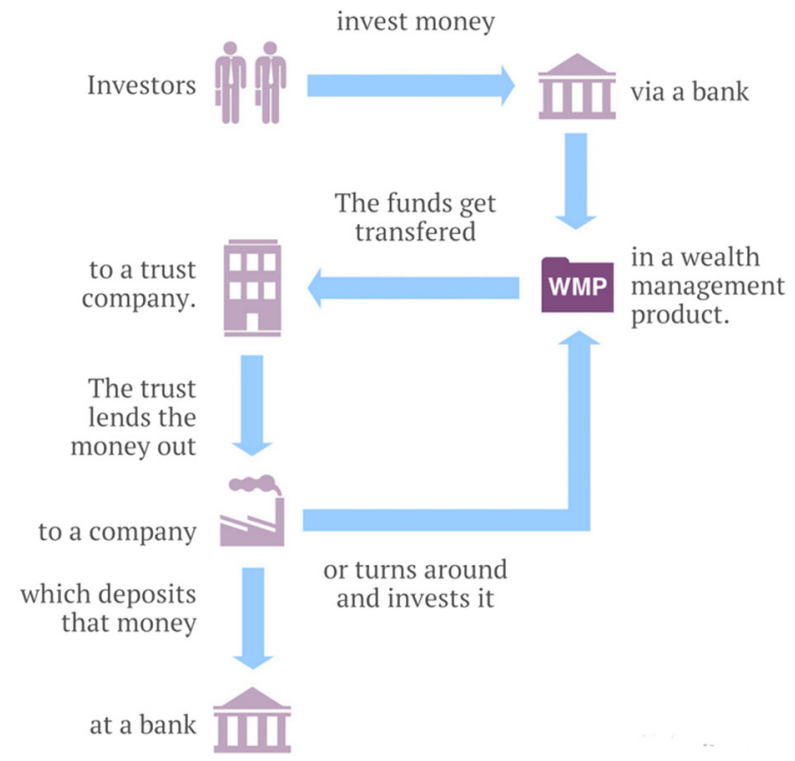

Fig. 1 Wealth management and shadow banking in China. Source: Guilford (2014)

called bank-Trust cooperation model, banks channel funds to Trusts via entrusted loans. Entrusted loans are another important component of the shadow banking system. These are loans made by firms in the non-financial economy that are run through banks for legal reasons but with the banks indemnified from the credit risk of the borrower by the non-financial firm. Some entrusted loans are funded by state-owned enterprises as a way of profiting from their ability to borrow cheaply and in large volume by on-lending the funds they obtain. However, the majority of

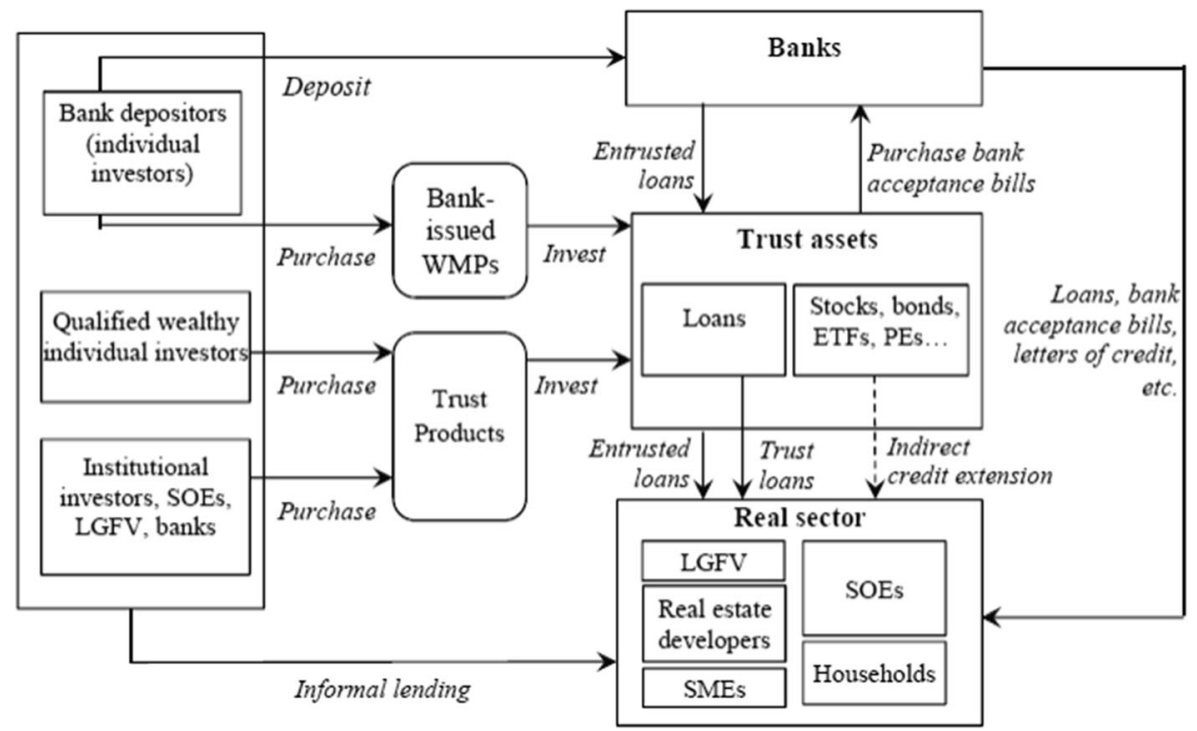

Fig. 2 An illustration of trust companies' business model. Source Li (2014) 
entrusted loans appear to be lent within a corporate group, with HKMA (2014) showing $74 \%$ of this lending was to subsidiaries and $7 \%$ to other affiliates. Lending within a corporate group would not be considered shadow banking under standard definitions, but it is difficult to separate this out from loans to unrelated parties. This analytical problem leads to most SB estimations calculations treating all entrusted loans as shadow banking, even though this doubtless exaggerates the size of shadow banking in China.

As reported by Elliott et al. (2015), other instruments usually classified as part of shadow banking are the following:

- Bankers Acceptances - notes issued by banks that promise to pay a fixed amount a few months in the future. Generally these are supposed to be issued in connection with a non-financial transaction, such as a purchase of goods, but reports suggest they are often used more loosely.

- Micro-finance companies - these are separately regulated financial firms that are licensed to lend in small amounts to help encourage credit access for small and rural borrowers.

- Financial leasing - this represents leasing of all kinds that is not already on a bank or Trust company balance sheet and is not a short-term operating lease.

- Guarantees - Guarantee companies in China provide financial guarantees, including those to facilitate shadow banking transactions. Many guarantee companies have branched out to make direct loans, even though they do not have legal licenses to do so.

- Pawn shops and various unofficial lenders - Pawn shops are important lenders to some households and small businesses. In addition, there are other types of lenders that operate informally or even clearly illegally.

- Trust Beneficiary Rights (TBRs) - these are effectively a simple form of derivative transaction whereby the purchaser of the TBR receives all or a stated proportion of the returns accruing to a Trust. Banks sometimes use TBRs as part of complex shadow banking transactions to keep the economic benefits of a loan without showing it as a loan on their balance sheets, but moving it to a more favorably treated investment category.

- Inter-bank market activities - another substitute for formal deposits is created using the inter-bank market. Despite its name, many participants in this market are not banks but are large corporations using a finance company subsidiary to participate. They can lend money to banks in deposit-like arrangements without being subject to caps on deposit rates and without forcing banks to incur many of the regulatory costs of deposits, such as triggering the minimum reserve requirements.

Virtually all estimates of the size of shadow banking in China start with figures provided by the PBOC on the level of "Total Social Financing" (TSF). The PBOC provides these figures for the year 2002 and onwards, in recognition that banks ceased to be the only finance sources that mattered and it became necessary to examine a fuller range of financial activity. Shadow banking comprises much of the non-bank TSF activities and Fig. 3 reports the magnitudes of the various components over time. In line with the most of the literature, e.g. Wang and Li 


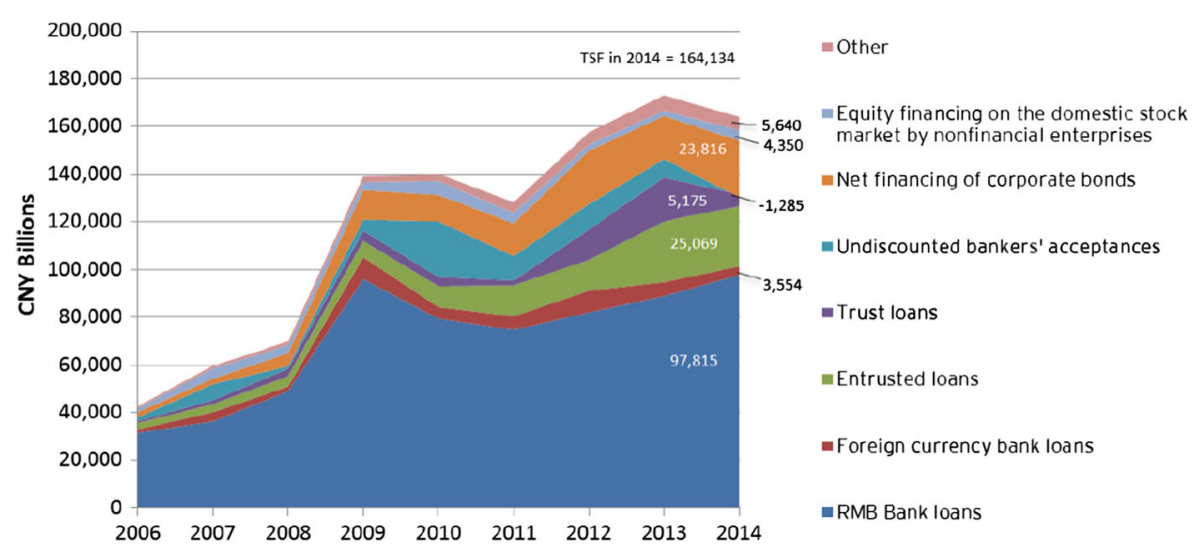

Fig. 3 Net flows of total social financing. Source: Elliott et al. (2015)

(2013), Elliott et al. (2015), in our paper the size of the shadow banking system in China is calculated through total amount of Trust loans, entrust loans and the financial products of commercial banks that are cross-cooperated by banks and trust companies. Zhu, Ng, and Jiang (2013) estimate that these three elements occupy at least half of the total shadow banking size in China and that the statistical data of remaining shadow banking activity is too separated and difficult to estimate.

\section{Empirical analysis}

Our empirical analysis aims to shed light on the impact of Chinese shadow banking system on the effectiveness of monetary policy. As the recent literature shows that bank lending is increasingly independent from the PBOC, it remains an open question whether shadow banking lending supports, weakens, or amplifies the effects of monetary policy. Theoretically, the shadow banking system transmission mechanism is negatively related to the efficiency of monetary policy. For example, the tight monetary policy aims to reduce the money supply in the market, which is followed by the increase of the loan interest rate. As the cost of financing increases, medium and small sized firms might have difficulties obtaining loans from banks. When this occurs, enterprises may prefer to finance through shadow banking because credit services of the shadow banking system

Table 1 Augmented DickeyFuller test in levels

\begin{tabular}{lc}
\hline ADF-Fisher Chi-square & $P$-value \\
\hline GDP & 0.0737 \\
CPI & 0.0000 \\
SBS & 0.0000 \\
RF & 0.0635 \\
M1 & 0.2242 \\
\hline
\end{tabular}


Table 2 Augmented DickeyFuller test in differences

\begin{tabular}{lc}
\hline ADF-Fisher Chi -square & P-value \\
\hline$\Delta$ GDP & 0.0000 \\
$\Delta \mathrm{CPI}$ & 0.0071 \\
$\Delta \mathrm{SBS}$ & 0.0000 \\
$\Delta \mathrm{RF}$ & 0.0001 \\
$\Delta \mathrm{M} 1$ & 0.0000 \\
\hline
\end{tabular}

can offer low-interest loans to those companies. Under such circumstances, there is a reasonable possibility that the narrow money supply might rise or remain at the same level under this situation. Since the shadow banking system scale is highly developed, the tightening of monetary policy may not work and the inflation rate might actually rise. The credit creation function of the shadow banking system might affect the statistical accuracy of the money supply. However, the existence of the shadow banking system might benefit economic growth due to its cheap financing cost. Conscious of the complexities of the problem and data limitations, we take a natural first step to the research question by using a standard VAR model. The model is estimated by using monthly data from January 2002 to June 2014 from the Chinese WIND financial market and macro-economic dataset.

Variables The five variables that we use are:

1) GDP - proxied by Industrial production.

2) CPI: Consumer Price Index.

3) SBS: Size of the SB system China, calculated using monthly data of the total amount of trust loans, entrust loans and financial products of commercial banks.

4) RF: Base interest rate. The periods of credit services offered by the shadow banking system is usually less than one year. Hence, it is represented by the

Table 3 Optimal lags selection criteria

\begin{tabular}{lllllll}
\multicolumn{7}{l}{ VAR Lag Order Selection Criteria } \\
\hline Lag & LogL & LR & FPE & AIC & SC & HQ \\
\hline 0 & -1926.382 & NA & $543,676.3$ & 27.39549 & 27.50006 & 27.43799 \\
1 & -1823.296 & 197.3986 & $179,649.6$ & 26.28789 & 26.91529 & 26.54284 \\
2 & -1750.758 & 133.7582 & $91,655.82$ & 25.61359 & $\mathbf{2 6 . 7 6 3 8 2 *}$ & $\mathbf{2 6 . 0 8 1 0 0 *}$ \\
3 & -1723.778 & 47.83806 & $89,412.99$ & 25.58550 & 27.25855 & 26.26537 \\
4 & -1694.698 & $\mathbf{4 9 . 4 9 7 8 2 *}$ & $\mathbf{8 4 , 9 1 4 . 6 6 *}$ & $\mathbf{2 5 . 5 2 7 6 3 *}$ & 27.72351 & 26.41996 \\
5 & -1681.460 & 21.59314 & $101,358.7$ & 25.69447 & 28.41318 & 26.79926 \\
6 & -1660.271 & 33.06175 & $108,621.2$ & 25.74852 & 28.99006 & 27.06577 \\
7 & -1649.170 & 16.53258 & $135,137.1$ & 25.94567 & 29.71005 & 27.47539 \\
8 & -1636.041 & 18.62344 & $164,562.6$ & 26.11405 & 30.40125 & 27.85622 \\
\hline
\end{tabular}

*indicates lag order selected by the criterion 


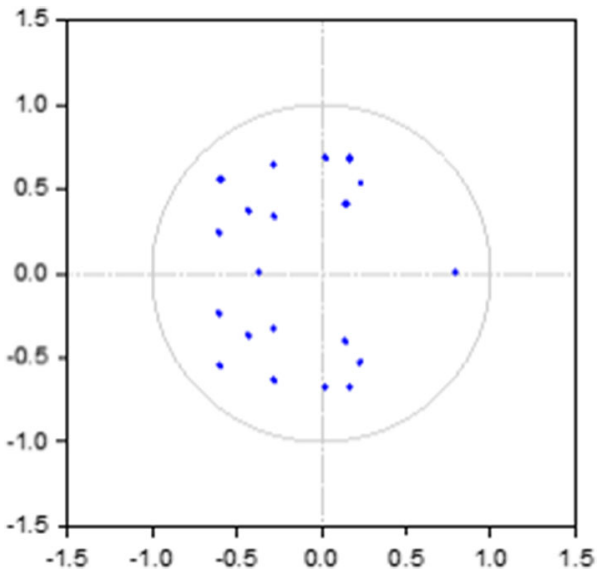

Fig. 4 Inverse roots of AR characteristic polynomial

Chinese short-term (6 to 12 months) loan interest rate. It changes frequently following the announcement of Chinese central bank.

5) M1: Narrow money supply in China.

Stationarity test We test for stationarity by the ADF test with trend and intercept. The results are reported in Table 1 , where $\times 1$ to $\times 5$ represent the 5 variables in the described order. As Table 1 shows, GDP, RF and M1 are non-stationary at 5\% confidence level. As a result we take the first difference of each variable and we perform the test again; the results in the Table 2 show that all first differences are stationary and that the maximum order of integration is $\mathrm{I}(1)$.

Table 4 Johansen Co-integration test

\section{M06 2014 M06}

Trend assumption: Linear deterministic trend

Series: GDP M1 RF SBS CPI

Lags interval (in first differences): 1 to 4

Unrestricted Cointegration Rank Test (Trace)

Hypothesized

Trace $\quad 0.05$

No. of CE(s)

Eigenvalue

Statistic

Critical Value

Prob.**

\begin{tabular}{|c|c|c|c|c|}
\hline None $*$ & 0.556952 & 212.5125 & 69.81889 & 0.0000 \\
\hline At most $1 *$ & 0.259986 & 94.47130 & 47.85613 & 0.0000 \\
\hline At most $2 *$ & 0.200774 & 50.81374 & 29.79707 & 0.0001 \\
\hline At most $3 *$ & 0.086623 & 18.31762 & 15.49471 & 0.0183 \\
\hline At most $4 *$ & 0.035091 & 5.179634 & 3.841466 & 0.0228 \\
\hline
\end{tabular}

Trace test indicates 5 cointegrating eqn(s) at the 0.05 level

*denotes rejection of the hypothesis at the 0.05 level

**MacKinnon-Haug-Michelis (1999) $p$-values 
Table 5 Granger Causality Tests

VAR Granger Causality/Block Exogeneity Wald Tests

Sample: 2002 M01 2014 M06

Excluded

Chi-sq

df

Prob.

Dependent variable: GDP

$\begin{array}{llll}\text { M1 } & 2.129897 & 4 & 0.7119 \\ \text { RF } & 16.55801 & 4 & 0.0024 \\ \text { SBS } & 0.268956 & 4 & 0.9917 \\ \text { CPI } & 7.907255 & 4 & 0.0950 \\ \text { All } & 35.46794 & 16 & 0.0034\end{array}$

Dependent variable: M1

$\begin{array}{llll}\text { GDP } & 0.435110 & 4 & 0.9795 \\ \text { RF } & 11.02182 & 4 & 0.0263 \\ \text { SBS } & 1.244395 & 4 & 0.8707 \\ \text { CPI } & 1.902746 & 4 & 0.7536 \\ \text { All } & 14.60704 & 16 & 0.5536\end{array}$

Dependent variable: RF

$\begin{array}{ll}\text { GDP } & 2.696623 \\ \text { M1 } & 1.078552 \\ \text { SBS } & 1.140827 \\ \text { CPI } & 8.730744 \\ \text { All } & 14.06500\end{array}$

$\begin{array}{ll}4 & 0.6098 \\ 4 & 0.8977 \\ 4 & 0.8877 \\ 4 & 0.0682 \\ 16 & 0.5939\end{array}$

Dependent variable: SBS

$\begin{array}{llll}\text { GDP } & 21.03281 & 4 & 0.0003 \\ \text { M1 } & 32.83687 & 4 & 0.0000 \\ \text { RF } & 0.876610 & 4 & 0.9279 \\ \text { CPI } & 1.754459 & 4 & 0.7808 \\ \text { All } & 53.74466 & 16 & 0.0000 \\ \text { Dependent variable: CPI } & & & \\ \text { GDP } & 2.483935 & 4 & 0.6475 \\ \text { M1 } & 9.016734 & 4 & 0.0607 \\ \text { RF } & 14.53873 & 4 & 0.0058 \\ \text { SBS } & 1.708954 & 4 & 0.7891 \\ \text { All } & 31.41556 & 16 & 0.0119\end{array}$

Optimal lags We determine the appropriate maximum lag length for the variables in the VAR, using the usual information criteria, such as AIC, SIC. Table 3 lists the recognized best lag length of the VAR according to five measurements. As the results indicate, the minimum lag length selected by LR, FPE and AIC is 4 lags, whereas the minimum lag length of SC and $\mathrm{HQ}$ is 2 lags. Hence, according to the popularity criteria we choose a 4 lag length as the appropriate lag of the VAR model. 

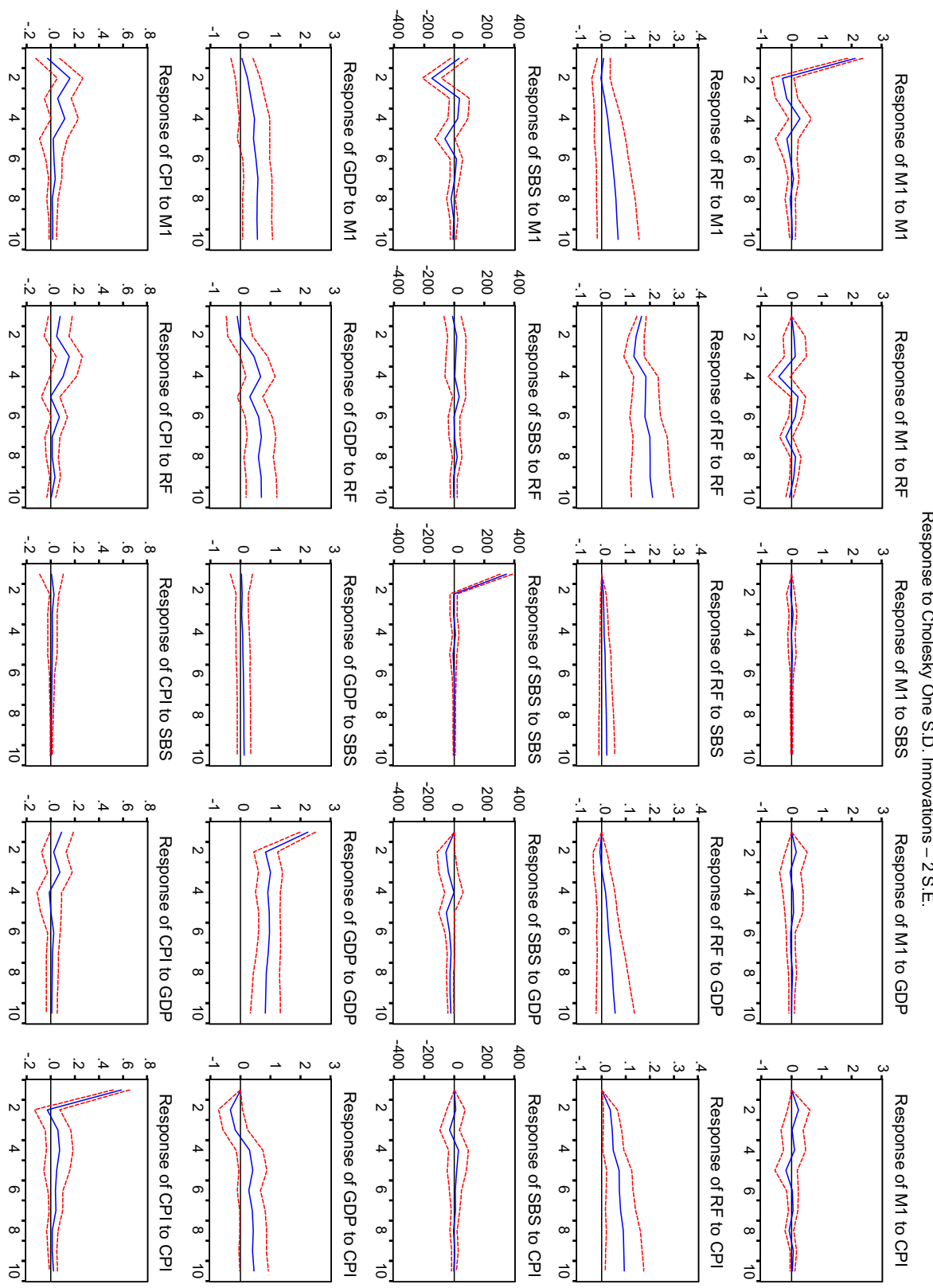

Fig. 5 Impulse response functions

Unit root test In order to ensure that the VAR model is stable we test that all the inverse characteristic roots of VAR lie inside the unit circle. Figure 4 shows that all the inverse root of the AR characteristic polynomial locate inside of the unit circle. Therefore VAR model is stationary and available to be used to work with other tests. 
Table 6 Impulse-response magnitudes (M1 before RF)

\begin{tabular}{|c|c|c|c|c|c|}
\hline Response of LOG_M1: Period & LOG_M1 & LOG_RF & LOG_SBS & LOG_GDP & LOG_CPI \\
\hline \multirow[t]{2}{*}{1} & 0.008893 & 0.000000 & 0.000000 & 0.000000 & 0.000000 \\
\hline & $(0.00052)$ & $(0.00000)$ & $(0.00000)$ & $(0.00000)$ & $(0.00000)$ \\
\hline \multirow[t]{2}{*}{2} & -0.001096 & $-1.70 \mathrm{E}-05$ & 0.001936 & 0.000188 & 0.001574 \\
\hline & $(0.00080)$ & $(0.00078)$ & $(0.00077)$ & $(0.00076)$ & $(0.00079)$ \\
\hline \multirow[t]{2}{*}{3} & -0.000684 & 0.000120 & -0.000641 & -0.000135 & 0.001096 \\
\hline & $(0.00080)$ & $(0.00079)$ & $(0.00077)$ & $(0.00076)$ & $(0.00079)$ \\
\hline \multirow[t]{2}{*}{4} & 0.001527 & -0.001886 & 0.001104 & 0.000290 & 0.001041 \\
\hline & $(0.00081)$ & $(0.00079)$ & $(0.00076)$ & $(0.00073)$ & $(0.00075)$ \\
\hline Response of LOG_RF: Period & LOG_M1 & LOG_RF & LOG_SBS & LOG_GDP & LOG_CPI \\
\hline \multirow[t]{2}{*}{1} & $-6.92 \mathrm{E}-06$ & 0.000674 & 0.000000 & 0.000000 & 0.000000 \\
\hline & $(5.6 \mathrm{E}-05)$ & $(3.9 \mathrm{E}-05)$ & $(0.00000)$ & $(0.00000)$ & $(0.00000)$ \\
\hline \multirow[t]{2}{*}{2} & $-7.39 \mathrm{E}-05$ & 0.000588 & $2.31 \mathrm{E}-05$ & $-4.30 \mathrm{E}-05$ & 0.000122 \\
\hline & $(7.7 \mathrm{E}-05)$ & $(6.8 \mathrm{E}-05)$ & $(5.8 \mathrm{E}-05)$ & $(5.8 \mathrm{E}-05)$ & $(6.0 \mathrm{E}-05)$ \\
\hline \multirow[t]{2}{*}{3} & $-3.03 \mathrm{E}-05$ & 0.000537 & $-3.17 \mathrm{E}-05$ & $-1.23 \mathrm{E}-05$ & 0.000148 \\
\hline & $(9.0 \mathrm{E}-05)$ & $(8.4 \mathrm{E}-05)$ & $(7.8 \mathrm{E}-05)$ & $(7.1 \mathrm{E}-05)$ & $(7.8 \mathrm{E}-05)$ \\
\hline \multirow[t]{2}{*}{4} & $-1.36 \mathrm{E}-05$ & 0.000710 & $-4.69 \mathrm{E}-05$ & $1.99 \mathrm{E}-05$ & 0.000164 \\
\hline & $(0.00011)$ & $(0.00010)$ & $(8.8 \mathrm{E}-05)$ & $(7.6 \mathrm{E}-05)$ & $(8.3 \mathrm{E}-05)$ \\
\hline Response of LOG_SBS: Period & LOG_M1 & LOG_RF & LOG_SBS & LOG_GDP & LOG_CPI \\
\hline \multirow[t]{2}{*}{1} & 0.134731 & 0.009924 & 0.419338 & 0.000000 & 0.000000 \\
\hline & $(0.03560)$ & $(0.03471)$ & $(0.02454)$ & $(0.00000)$ & $(0.00000)$ \\
\hline \multirow[t]{2}{*}{2} & -0.186571 & 0.032980 & -0.183078 & -0.011754 & 0.057156 \\
\hline & $(0.04290)$ & $(0.04072)$ & $(0.03911)$ & $(0.03726)$ & $(0.03908)$ \\
\hline \multirow[t]{2}{*}{3} & 0.004789 & -0.024754 & -0.026557 & -0.003784 & -0.025209 \\
\hline & $(0.04442)$ & $(0.04353)$ & $(0.04256)$ & $(0.04348)$ & $(0.04442)$ \\
\hline \multirow[t]{2}{*}{4} & -0.005390 & -0.051669 & 0.108986 & 0.009791 & 0.028276 \\
\hline & $(0.04455)$ & $(0.04409)$ & $(0.04171)$ & $(0.04202)$ & $(0.04333)$ \\
\hline Response of LOG_GDP:Period & LOG_M1 & LOG_RF & LOG_SBS & LOG_GDP & LOG_CPI \\
\hline \multirow[t]{2}{*}{1} & -0.000199 & -0.000615 & 0.000842 & 0.008424 & 0.000000 \\
\hline & $(0.00070)$ & $(0.00070)$ & $(0.00070)$ & $(0.00049)$ & $(0.00000)$ \\
\hline \multirow[t]{2}{*}{2} & 0.000341 & -0.000148 & $2.32 \mathrm{E}-05$ & 0.002943 & -0.001367 \\
\hline & $(0.00078)$ & $(0.00077)$ & $(0.00077)$ & $(0.00074)$ & $(0.00075)$ \\
\hline \multirow[t]{2}{*}{3} & 0.000179 & 0.001595 & 0.000151 & 0.003487 & -0.001013 \\
\hline & $(0.00084)$ & $(0.00083)$ & $(0.00082)$ & $(0.00074)$ & $(0.00076)$ \\
\hline \multirow[t]{2}{*}{4} & 0.000533 & 0.002285 & 0.000639 & 0.002948 & 0.000826 \\
\hline & $(0.00088)$ & $(0.00087)$ & $(0.00084)$ & $(0.00073)$ & $(0.00075)$ \\
\hline Response of LOG_CPI:Period & LOG_M1 & LOG_RF & LOG_SBS & LOG_GDP & LOG_CPI \\
\hline \multirow[t]{2}{*}{1} & $6.53 \mathrm{E}-06$ & 0.000197 & 0.000270 & 0.000346 & 0.002764 \\
\hline & $(0.00023)$ & $(0.00023)$ & $(0.00023)$ & $(0.00023)$ & $(0.00016)$ \\
\hline \multirow[t]{2}{*}{2} & 0.000942 & $1.29 \mathrm{E}-05$ & 2.23E-05 & 4.43E-05 & 0.000350 \\
\hline & $(0.00025)$ & $(0.00024)$ & $(0.00024)$ & $(0.00024)$ & $(0.00025)$ \\
\hline \multirow[t]{2}{*}{3} & 0.000377 & 0.000434 & 0.000145 & 0.000245 & 0.000755 \\
\hline & $(0.00027)$ & $(0.00026)$ & $(0.00026)$ & $(0.00024)$ & $(0.00025)$ \\
\hline \multirow[t]{2}{*}{4} & 0.000745 & 0.000191 & 0.000187 & -0.000120 & 0.001046 \\
\hline & $(0.00028)$ & $(0.00027)$ & $(0.00026)$ & $(0.00025)$ & $(0.00025)$ \\
\hline
\end{tabular}

Cholesky Ordering LOG_M1, LOG_RF, LOG_SBS, LOG_GDP, LOG_CPI 
Table 7 Impulse-response magnitudes (RF before M1)

\begin{tabular}{|c|c|c|c|c|c|}
\hline Response of LOG_RF: Period & LOG_RF & LOG_M1 & LOG_SBS & LOG_GDP & LOG_CPI \\
\hline \multirow[t]{2}{*}{1} & 0.000674 & 0.000000 & 0.000000 & 0.000000 & 0.000000 \\
\hline & $(3.9 \mathrm{E}-05)$ & $(0.00000)$ & $(0.00000)$ & $(0.00000)$ & $(0.00000)$ \\
\hline \multirow[t]{2}{*}{2} & 0.000589 & $-6.79 \mathrm{E}-05$ & $2.31 \mathrm{E}-05$ & $-4.30 \mathrm{E}-05$ & 0.000122 \\
\hline & $(6.8 \mathrm{E}-05)$ & $(6.0 \mathrm{E}-05)$ & $(5.8 \mathrm{E}-05)$ & $(5.8 \mathrm{E}-05)$ & $(6.0 \mathrm{E}-05)$ \\
\hline \multirow[t]{2}{*}{3} & 0.000537 & $-2.48 \mathrm{E}-05$ & $-3.17 \mathrm{E}-05$ & $-1.23 \mathrm{E}-05$ & 0.000148 \\
\hline & $(8.4 \mathrm{E}-05)$ & $(7.9 \mathrm{E}-05)$ & $(7.8 \mathrm{E}-05)$ & $(7.1 \mathrm{E}-05)$ & $(7.8 \mathrm{E}-05)$ \\
\hline \multirow[t]{2}{*}{4} & 0.000711 & $-6.28 \mathrm{E}-06$ & $-4.69 \mathrm{E}-05$ & $1.99 \mathrm{E}-05$ & 0.000164 \\
\hline & $(0.00010)$ & $(9.1 \mathrm{E}-05)$ & $(8.8 \mathrm{E}-05)$ & $(7.6 \mathrm{E}-05)$ & $(8.3 \mathrm{E}-05)$ \\
\hline Response of LOG_M1: Period & LOG_RF & LOG_M1 & LOG_SBS & LOG_GDP & LOG_CPI \\
\hline \multirow[t]{2}{*}{1} & $-9.13 \mathrm{E}-05$ & 0.008893 & 0.000000 & 0.000000 & 0.000000 \\
\hline & $(0.00074)$ & $(0.00052)$ & $(0.00000)$ & $(0.00000)$ & $(0.00000)$ \\
\hline \multirow[t]{2}{*}{2} & $-5.75 \mathrm{E}-06$ & -0.001096 & 0.001936 & 0.000188 & 0.001574 \\
\hline & $(0.00079)$ & $(0.00080)$ & $(0.00077)$ & $(0.00076)$ & $(0.00079)$ \\
\hline \multirow[t]{2}{*}{3} & 0.000127 & -0.000683 & -0.000641 & -0.000135 & 0.001096 \\
\hline & $(0.00079)$ & $(0.00080)$ & $(0.00077)$ & $(0.00076)$ & $(0.00079)$ \\
\hline \multirow[t]{2}{*}{4} & -0.001902 & 0.001508 & 0.001104 & 0.000290 & 0.001041 \\
\hline & $(0.00080)$ & $(0.00080)$ & $(0.00076)$ & $(0.00073)$ & $(0.00075)$ \\
\hline Response of LOG_SBS: Period & LOG_RF & LOG_M1 & LOG_SBS & LOG_GDP & LOG_CPI \\
\hline \multirow[t]{2}{*}{1} & 0.008540 & 0.134826 & 0.419338 & 0.000000 & 0.000000 \\
\hline & $(0.03646)$ & $(0.03559)$ & $(0.02454)$ & $(0.00000)$ & $(0.00000)$ \\
\hline \multirow[t]{2}{*}{2} & 0.034893 & -0.186222 & -0.183078 & -0.011754 & 0.057156 \\
\hline & $(0.04352)$ & $(0.04283)$ & $(0.03911)$ & $(0.03726)$ & $(0.03908)$ \\
\hline \multirow[t]{2}{*}{3} & -0.024802 & 0.004535 & -0.026557 & -0.003784 & -0.025209 \\
\hline & $(0.04350)$ & $(0.04441)$ & $(0.04256)$ & $(0.04348)$ & $(0.04442)$ \\
\hline \multirow[t]{2}{*}{4} & -0.051611 & -0.005920 & 0.108986 & 0.009791 & 0.028276 \\
\hline & $(0.04407)$ & $(0.04437)$ & $(0.04171)$ & $(0.04202)$ & $(0.04333)$ \\
\hline Response of LOG_GDP: Period & LOG_RF & LOG_M1 & LOG_SBS & LOG_GDP & LOG_CPI \\
\hline \multirow[t]{2}{*}{1} & -0.000613 & -0.000205 & 0.000842 & 0.008424 & 0.000000 \\
\hline & $(0.00070)$ & $(0.00070)$ & $(0.00070)$ & $(0.00049)$ & $(0.00000)$ \\
\hline \multirow[t]{2}{*}{2} & -0.000151 & 0.000339 & $2.32 \mathrm{E}-05$ & 0.002943 & -0.001367 \\
\hline & $(0.00077)$ & $(0.00078)$ & $(0.00077)$ & $(0.00074)$ & $(0.00075)$ \\
\hline \multirow[t]{2}{*}{3} & 0.001593 & 0.000195 & 0.000151 & 0.003487 & -0.001013 \\
\hline & $(0.00083)$ & $(0.00083)$ & $(0.00082)$ & $(0.00074)$ & $(0.00076)$ \\
\hline \multirow[t]{2}{*}{4} & 0.002279 & 0.000556 & 0.000639 & 0.002948 & 0.000826 \\
\hline & $(0.00088)$ & $(0.00086)$ & $(0.00084)$ & $(0.00073)$ & $(0.00075)$ \\
\hline Response of LOG_CPI: Period & LOG_RF & LOG_M1 & LOG_SBS & LOG_GDP & LOG_CPI \\
\hline \multirow[t]{2}{*}{1} & 0.000197 & $8.55 \mathrm{E}-06$ & 0.000270 & 0.000346 & 0.002764 \\
\hline & $(0.00023)$ & $(0.00023)$ & $(0.00023)$ & $(0.00023)$ & $(0.00016)$ \\
\hline \multirow[t]{2}{*}{2} & $3.22 \mathrm{E}-06$ & 0.000942 & $2.23 \mathrm{E}-05$ & 4.43E-05 & 0.000350 \\
\hline & $(0.00025)$ & $(0.00025)$ & $(0.00024)$ & $(0.00024)$ & $(0.00025)$ \\
\hline \multirow[t]{2}{*}{3} & 0.000430 & 0.000382 & 0.000145 & 0.000245 & 0.000755 \\
\hline & $(0.00026)$ & $(0.00026)$ & $(0.00026)$ & $(0.00024)$ & $(0.00025)$ \\
\hline \multirow[t]{2}{*}{4} & 0.000183 & 0.000747 & 0.000187 & -0.000120 & 0.001046 \\
\hline & $(0.00028)$ & $(0.00028)$ & $(0.00026)$ & $(0.00025)$ & $(0.00025)$ \\
\hline
\end{tabular}

Cholesky Ordering LOG_RF, LOG_M1, LOG_SBS, LOG_GDP, LOG_CPI 
Co-integration test Given 4 lags, we test for co-integration of the I(1) series. Table 4 shows that stable long-term co-integration relationships exists for the five variables at the $5 \%$ significance level.

Granger causality test Following the standard procedure of Toda and Yamamoto (1995) as illustrated in Lütkepohl (2006), we test for Granger Causality (GC) by considering 4 lags in the Wald test and then considering the extra lag due to I(1) series by adding a 5 th lag as exogenous variables. The results are reported in Table 5. We can notice the following relationships: Firstly the shadow banking system granger causality tests shows it affects the GDP at the 5\% significance level. Secondly, GDP and Shadow Banking influence the monetary aggregate $\mathrm{M} 1$ at the $5 \%$ and $10 \%$ significance levels. Thirdly, the shadow banking system and money supply Granger cause the interest rate at the $10 \%$ significance level. Finally the interest rate seems to also Granger cause the shadow banking sector at the $10 \%$ significance level. Overall our results suggest that the shadow banking system has an impact on GDP, M1 and RF suggesting that it has a significant influence on the Chinese economy and monetary indicators.

Impulse-response functions We consider the log of all variables, so that the impact of Choleski one standard deviation innovation can be measured in percentage terms. The response functions of M1, RF, SBS, GDP and CPI to each other, with the confidence intervals, are illustrated in Fig. 5 (Tables 6 and 7). ${ }^{14}$

We notice that the response of the shadow banking system size to M1 in the beginning is positive and the largest in comparison with the other three variables. Moreover, according to the chart, even if a following negative response of the shadow banking system follows the positive shock, the effect stays positive after 3 lags and then gradually fades to zero after lag 4 . We interpret this result as showing that loose monetary policy will initially increase the scale of shadow banking through supplying shadow banking with cheap liquidity, but then this is later partially offset by decreasing demand for shadow banking products. Related to this, we note the initial positive response of shadow banking to a rise in interest rates which is consistent with the fact that if the financing costs of banks are high the shadow banking can offer the cheap financing products. We also notice a small but consistently positive effect of shadow banking on GDP. In results, available from the authors upon request, we estimate a VECM model that confirms the main properties noticed in the impulse-response analysis. ${ }^{15}$

\section{Conclusions}

This paper has examined the relationship among Chinese shadow banking system size, the effectiveness of monetary policy and the economic growth in China. Our institutional review indicates that the shadow banking sector in China while growing rapidly,

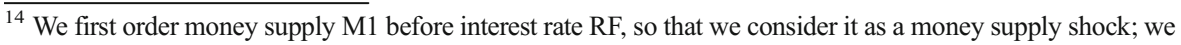
then order money supply M1 after interest rate RF, so that implicitly one can consider the shock to M1 as a money demand shock. We do not find significantly different results with the two orderings. We thank a referee for this useful remark.

${ }^{15}$ Since we estimate it by OLS, we take the results as potentially affected by endogeneity biases, nevertheless the estimation provides a useful check.
} 
is still at a developing stage in comparison with the shadow banking sector in western countries. The financing products of the western shadow banking sector are more complex and developed than those of China. However, we notice that some fundamental characteristics of the shadow banking system are the same in both Western economies and China these include high leverage, credit creation, maturity mismatch and lack of transparency.

This paper has used empirical tests to show that the shadow banking system can positively impact on economic growth, interest rates and money supply increases in China. Our empirical analysis while suggesting that the shadow banking sector can positively affect economic growth cannot say much about the magnitude of this effect.

Moreover, the effect of shadow banking sector of a money supply increase is significant in comparison with other variables. We contribute to the recent debate on the effect of bank lending on the efficacy of the monetary policy in China and show that Shadow Banking works independently from standard monetary policy by amplifying increases in the money supply but weakening the effects of restrictive interest ratebased monetary policy decisions. Our results provide some empirical support to the papers of Fernald et al. (2014) and Hou and Wang (2013) in showing that bank lending is increasingly independent from the PBOC.

As a suggested agenda for future research, it is clear that the shadow banking sector needs to be fully incorporated into the modelling of the Chinese financial sector and the impact of the financial sector on the Chinese economy and vice-versa needs to be appropriately modelled. It is also likely that in future years the Shadow Banking sector in China will itself evolve and become both more sophisticated and perhaps more regulated than it currently is. Chinese policy makers are unlikely to permit such a rapidly growing and important part of their financial system to evolve without greater regulation. This will inevitably change and influence the way that the Shadow Banking system affects the implementation of monetary policy.

Acknowledgements We are grateful to seminar participants at University of Reading, University of Birmingham, City, University of London and the European Economic and Finance Society annual conference 2015 for many helpful comments. We are also grateful to two anonymous for their extensive comments that led to significant improvements in the paper.

Open Access This article is distributed under the terms of the Creative Commons Attribution 4.0 International License (http://creativecommons.org/licenses/by/4.0/), which permits unrestricted use, distribution, and reproduction in any medium, provided you give appropriate credit to the original author(s) and the source, provide a link to the Creative Commons license, and indicate if changes were made.

\section{References}

Adrian T, Ashcraft A (2012) Shadow banking: a review of the literature. Federal Reserve Bank of New York Staff Reports, No 580e

Bernanke B (2012) Fostering financial stability. Speech given at the Federal Reserve Bank of Atlanta, Georgia, April 9, 2012

Brunnermeier MK (2009) Deciphering the liquidity and credit crunch 20072008. J Econ Perspect 23:77-100

Economist (2014a) A question of trust. In special report: International banking, May, 10

Economist (2014b) Shadow banking in China: Credit paroled, February, 1

Elliott D, Kroeber A, Qiao Y (2015) Shadow banking in China: a primer. Economic Studies at Brookings, March 
Fernald J, Spiegel MM, Swanson ET (2014) Monetary Policy Effectiveness in China: Evidence from a FAVAR Model. Federal Reserve Bank of San Francisco Working Paper 2014/7

FRBSF (2013) Shadow banking in China: expanding scale, Evolving Structure. Federal Reserve Bank of San Francisco, Country Analysis Unit, Asia Focus

FSB (2013) Global shadow banking monitoring report 2013, November

FSB (2014) Global shadow banking monitoring report 2014, November

Gao S, Wang Q (2014) Chasing the shadow in different worlds: shadow banking and pts regulation in the U.S. and China. Manchester. J Int Econ Law 11:421-458

Gennaioli N, Shleifer A, Vishny RW (2013) A model of shadow banking. J Financ 68:1331-1363

Guilford G (2014) Five carts to explain China's shadow banking system. QUARTZ. Available at: http://qz. com/175590/five-charts-to-explain-chinasshadow-banking-system-and-how-it-could-make-a-slowdowneven-uglier/

HKMA (2014) Half-yearly monetary and financial stability report. Hong Kong Monetary Authority

Hou X, Wang Q (2013) Implications of banking marketization for the lending channel of monetary policy transmission: evidence from China. J Macroecon 38:442-451

Li T (2014) Shadow banking in China: expanding scale, evolving structure. J Financial Econ Policy 6:198211

Li J, Tian G (2011) An Analysis of the Top Tier Design of the Reform of the Regulation of Shadow Banking, 8 Hongguan Jingji Yanjiu [Macro-Economic Research]

Li J, Hsu S, Qin Y (2014) Shadow banking in China: institutional risks. China Econ Rev 31:119-129

Lütkepohl H (2006) New introduction to multiple time series analysis. Springer, Berlin

MacKinnon J, Haug A, Michelis L (1999) Numerical distribution functions of likelihood ratio tests for cointegration, Journal of Applied Econometrics, 14(5);563-577

Montes-Negret F (1995) China's credit plan: an overview. Oxf Rev Econ Policy 11:25-42

PBOC (2012) Connotations and Extensions of the Shadow Banking System. Financial Development Review, no.8, August, p 57-73 (in Chinese)

PBOC (2013) Financial Stability Report. June 2013

Pozsar Z, Singh M (2011) The Non-Bank-Bank Nexus and the Shadow Banking System. IMF Working Paper $11 / 289$

Pozsar Z, Adrian T, Ashcraft A, Boesky H (2012) Shadow Banking. Federal Reserve Bank of New York, Staff Reports, no 458, February

Sun R (2013) Does monetary policy matter in China? A narrative approach. China Econ Rev 26:56-74

Tao D, Deng W (2013) China: Shadow Banking - Road to Heightened Risks. Credit Suisse Economics Research, February, 22

Toda HY, Yamamoto T (1995) Statistical inferences in vector autoregressions with possibly integrated processes. J Econ 66:225-250

Wang BL, Li JJ (2013) The size of Chinese shadow Bank, Risk Assessment and Supervision Countermeasures. J Cent Univ Financ Econ:2013-2005

Xianrong Y, (2009) Financial Analysis on Credit Crisis of Shadow Banking System Jianghai Academic Journal. 3, p.019

Xiao LQ, Luo Y, Zou TJ (2012) An in-depth study of shadow banks in China. China Merchants Securities Research Report (in Chinese)

Zhu H, Ng G, Jiang L (2013) Shadow Banking in China. JPMorgan, Economic Research Global Data Watch. May 2013 